\title{
Exploring the impact of sustainability (ESG) disclosure on firm value and financial performance (FP) in airline industry: the moderating role of size and age
}

\author{
Yaghoub Abdi $^{1}$ (D) Xiaoni Li ${ }^{1}$ (D) Xavier Càmara-Turull ${ }^{1}$ (D)
}

Received: 11 January 2021 / Accepted: 8 July 2021 / Published online: 2 August 2021

(C) The Author(s) 2021, corrected publication 2021

\begin{abstract}
This study aims at exploring the impact of ESG scores on the value and FP of firms in the airline industry. The potential moderating role of firm size and age has also been studied in an effort to disentangle their relationships in this context. In particular, the analysis involves interaction effects for two types of firms: full-service and low-cost carriers. Based on the collected data from 38 airlines worldwide for the period 2009 to 2019, we observed that contributions to governance initiatives improve a firm's market-to-book ratio. We also found that a firm's participation in social and environmental activities is positively and significantly rewarded by a higher level of financial efficiency. Additionally, firm size is the relevant moderator for the association between sustainability disclosure and both firm value and FP in the air transport industry. We therefore propose that a managerial strategy of participating in these initiatives may adapt them based on their total assets as proxy of firm size. In regard to firm age, we did not find it to be a significant moderator.
\end{abstract}

Keywords Sustainability $\cdot$ Firm value $\cdot$ Financial performance $\cdot$ Airline industry $\cdot$ Firm age $\cdot$ Firm size

\section{Introduction}

The presence of sustainability standards can impact the financial status of the firm. These initiatives often entail committing financial resources to procuring eco-friendly equipment, launching high-quality standards for products and developing safety programs (Park et al., 2017). However, despite these significant short-term costs for a firm, it can then benefit from these sustainability investments by establishing a long-term

Yaghoub Abdi

yaghoub.abdi@urv.cat

Xiaoni Li

xiaoni.li@urv.cat

Xavier Càmara-Turull

xavier.camara@urv.cat

1 Department of Business Management, Universitat Rovira i Virgili, Reus, Spain 
basis for survival and may enjoy success in promoting products and services (Branco $\&$ Rodrigues, 2006). Consequently, for the benefit of managers and executives, scholars have actively attempted to deliver work that addresses the consequences of sustainability initiatives on firm performance and value (Park et al., 2017). In particular, in the tourism and hospitality industry, a growing number of studies focus on the topic in providing managerial insights to better handle the issue for a firms such as airlines, hotels, restaurants and casinos (see, for example, Lee et al., 2013; Theodoulidis et al., 2017; Park \& Lee, 2009; Kim \& Lee, 2020).

Nevertheless, the literature has yet to produce an entirely consistent and conclusive study demonstrating that the result of implementing sustainability initiatives to improve the financial performance and value of the firm is any one of positive, negative, curvilinear or insignificant (Casado-Díaz et al., 2014; Miralles-Quirós et al., 2019; Moore, 2001). Therefore, more empirical work is required to investigate the economic implications of sustainability in terms of various methodologies and samples (Lee et al., 2013; Park et al., 2017). Sustainability is often discussed in the context of three areas, environmental (Env), social (Soc) and governance (Gov) which are jointly captured by the acronym ESG (Gillan et al., 2010). Our first contribution is to the emerging stand of literature which suggests that ESG disclosure has a significant effect on an airline's market value and FP. Although its industry and products have been highlighted as significant factors differentiating a firm's attribute to sustainability initiatives, ones which potentially affect the empirical outcome (Lee et al., 2013; McWilliams \& Siegel, 2001), very few studies specifically investigate the airline industry (e.g., Lee \& Park, 2010; Yang \& Baasandorj, 2017). Given this gap, our second contribution is to produce additional empirical evidence for disentangling the ESGFP relationship which is valuable in the air transport context.

When exploring the direct association between the social and financial dimensions, a variety of firm characteristics can potentially moderate this relationship and are crucial for investigating the topic (Rowley \& Berman, 2000). Among these, Roberts (1992) discussed the role of size and age as firm-level attributes which could influence the firm's contribution to sustainability activities and are likely to assist in better understanding the ESG-FP relationship. Although the significant effect of these two variables was recently tested and confirmed by D'Amato and Falivena (2020) for a sample of Western European companies, no study has been conducted specifically for the airline industry. In addition, the sustainability literature generally neglects the type of airline. Our third contribution to the literature is, to the best of our knowledge, the first study that investigates the moderating effect of both size and age in an airline context. In particular, the topic critical for airlines since business prospects for these firms is subject to making progress in the sustainability dimension and in managing the alliance with government, industry and passengers (Daley, 2010; McManners, 2016b).

The objective of this study is twofold. First, it aims to explore the influence of ESG activities on FP and the value of airline firms. Second, we clarify the moderating role of size and age in the relationship between their sustainability and financial performance. For both objectives, we add to the empirical evidence on the impact of sustainability on financial performance in airline industry, adding size and age as moderators lacking in prior studies. This is critical for airlines since, as already mentioned, their business prospects are subject to progress in both sustainability and alliance management (Daley, 2010; McManners, 2016b). Accordingly, our study could help the executives to better allocate the firm's available resources to sustainability activities through adopting more efficient and robust approaches. Finally, we provide data by carrier type for managers of low-cost and full-service airlines when choosing among different sustainability initiatives. 
The structure of this study is as follows: Sect. 2 provides a conceptual background of the main research; Sect. 3 describes the methodology, design of the sample and variables; Sect. 4 provides the estimation results. Discussion is given in Sect. 5. The article ends with Conclusions, Implications and Future Research Directions as Sect. 6.

\section{Literature review and research hypotheses}

\subsection{ESG and firm's FP and value}

Over the last few decades, firms have been adopting sustainability initiatives for a variety of reasons ranging from voluntary engagements to de-facto requirements such as moral concerns, managerial "perks", social pressure or strategic reasons (Baron, 2000). These led businesses, as an indicator of their commitment to sustainability practices, to adopt such metrics in their strategies and decisions (Taherdangkoo et al., 2017). Firms are under pressure to provide an understandable metric of externalities regarding the eco-system and stakeholders (Jensen, 2020). In current practice, ESG has become the most widely used measurement of sustainability standards for holding firms accountable (Howard-Grenville, 2021).

Since the ultimate objective of a firm is to yield higher returns, the emerging question is how ESG reflects in its FP and value. The query has been tested in large number of empirical studies since 1972 (Margolis \& Walsh, 2001), these usually being justified by reference to one of several theoretical frameworks (Grosbois, 2012) which explain different aspects of ESG and help empirical investigations in understanding the impact on a firm's operations. Stakeholder theory is one of such approach which focuses on the relationship between a firm and all the bodies involved in its business domain. The theory directly connects the issue of sustainability to the degree in which a corporation regards or disregards shareholder benefits (Campbell, 2007; Driver \& Thompson, 2002). It emerged in response to the increasing need to link sustainability initiatives with a firm's interaction with its stakeholders (Diez-Cañamero et al., 2020). On this basis, the ESG score developed as being representative of the degree of a firm's integration of sustainability issues (Birindelli et al., 2018; Ferrero-Ferrero et al., 2016). By introducing ESG standards into a firm's financing strategy, stakeholders become a key driver and ESG a key metric, of corporate social responsibility (Diez-Cañamero et al., 2020). Stakeholder theory could also provide meaningful interpretations for a firms' financial benefits (Driver \& Thompson, 2002). In this sense, according to Gillan et al. (2021) ESG initiatives could drive value in two ways: first, an increase in shareholder value as a result of higher cash flow levels for the firm (e.g., higher reputation helps to better sell products to customers, highly trained employees improve productivity for a firm, etc.), and second, maximizing the shareholder utility arising from owning shares of in a sustainable firm.

Another approach discussed in linking ESG-FP and value is slack resources theory. From this perspective, business directors always strive to legitimately adjust a firm's current efficiency and to have surplus assets available to address unforeseen threats or prospects for improvements. The theory proposes investigating how "slack" recourses eventually impact a firm's performance. It considers business resources in four dimensions: a firm's objective is to obtain sustainable rents (above the average of competitors); resources are unequally distributed between firms and better resource management ensures better returns; better performance could be sustained as long as it valued by the customers; 
finally, innovation is the source of better performance (Taylor \& Oinas, 2006). From this standpoint, a firm's sources of competitive advantages are a set of tangible and intangible basic resources that come together coherently to enable the organization to reach its goals (Barrutia \& Echebarria, 2015). These resources are any assets that a firm employs to assist it to achieve goals or record the best performance in its key success factors (Barrutia \& Echebarria, 2015; Bryson et al., 2007). Therefore, according to resource-based theory, firms emphasize building competitive heterogeneity (Taylor \& Oinas, 2006), where their sustainability performance (ESG scores) could provide this benefit (Xie et al., 2019).

Empirically, the studies in the literature have produced mixed findings in regard to the relationship between ESG-FP and value (Gillan et al., 2021). First, most studies suggest a positive relationship between ESG, and FP and value (Aouadi \& Marsat, 2018; Brogi \& Lagasio, 2019; Jo \& Harjoto, 2011; Li et al., 2018; Long et al., 2020; Okafor et al., 2021; Pavlopoulos et al., 2019; Qureshi et al., 2020). Based on the outcome of these studies, sustainability initiatives can assist businesses to better meet stakeholder interests (Lee et al., 2013). The second category of empirical results suggests a negative relationship between ESG-FP and value (Buallay, 2019; Duque-Grisales \& Aguilera-Caracuel, 2019; Lee et al., 2009; Moore, 2001). This negative direction is probably due to the costs related to the implementation of these initiatives which are not reflected in a FP because these practices are not performed in the correct manner or because there is not enough institutional support to render them more visible, thus not ensuring approval from stakeholders. Finally, some researchers find that there is no specific relationship between ESG-FP and value since the cost involved in these activities will be paid-off by their benefits (Lahouel et al., 2019; McWilliams et al., 1999). Studies in this category hesitate to propose any direction in the relationship and discuss misspecifications in the research design such as nature of the industry under investigation (Lee et al., 2013).

The indefinite outcome of the research on the relationship between ESG-FP highlights the need for further investigation. Additional research is required on means of minimizing the bias in measurement and empirical approaches. Notably, the impact of industry, products and firm characteristics could affect the level and type of participation in sustainability initiatives and therefore result in differing empirical outcomes (Lee et al., 2013; McWilliams \& Siegel, 2001). Specifically, industry type, size and age are mentioned as firm-level attributes which could influence a firm's contribution to sustainability activities (Roberts, 1992). Consideration of these could assist in better understanding the ESG-FP relationship.

\subsection{Sustainability in the airline industry}

The air transport industry plays an important role in modern history. It is associated with a variety of ideas and implications connecting leisure, recreation, social contact and cultural exchange (Daley, 2010). For this reason, the industry is a major economic force in terms of its operations and impacts on related businesses, such as aircraft manufacturing and tourism (Belobaba et al., 2009). However, it is also regarded as one of the most challenged industries in regard to environmental impact and sustainability issues. It is one of the transportations subsectors which is individually assessed for environmental impact (Dessens et al., 2014). It has been claimed that aviation is the most challenging industry in which to implement sustainability initiatives (McManners, 2016a and b). This is due to doubts in regard to whether environmental sustainability is compatible with financial sustainability. Particularly, air transport is considered an excellent example of the direct contradiction between sustainability and economics policies and provides a good base for investigating 
how airlines can balance societal initiatives in their business strategy (McManners, 2016b). For airlines, financially sustainability is achievable, but environmentally sustainability poses the question of cost both on the firm and on the industry level. It means that "good policies achieve environmental sustainability at minimum cost in terms of other objectives or equivalently achieve the maximum environmental benefits consistent with an acceptable level of economic and financial performance" (Forsyth, 2011).

The type of airline has also been the focus of studies related to linking ESG-FP such as those of Seo et al. (2015) and of Yang and Baasandorj (2017). The topic is relevant, since in the transportation industry, the nature of the operation affects the sustainability performance (Borghesi et al., 2014). Low-cost airlines are found to pursue a cost leadership strategy by efficiently allocating available resources to achieve competitive advantage, while full-service airlines follow a hybrid strategy providing high-quality services as well as cost efficiency (Seo et al., 2015). However, although sustainability standards are defined based on common-sense standards in frameworks, the consequence could be different for full-service and low-cost airlines. Full-service carriers are found to be more environmentally friendly than their low-cost counterparts (Hagmann et al., 2015). This is because, for low-cost airlines, operational efficiency saving could not offset non-operational investment on sustainability initiatives (Nidumolu et al., 2009). Conversely, full-service airlines are characterized by a high to stakeholder expectation in terms of sustainability activities (Seo et al., 2015). The mixed findings on the ESG-FP association together with wide disparities in ESG participation between airlines encourage additional investigation in the industry. We, therefore, attempt to contribute to the literature by examining the influence of ESG disclosure on FP while to best of our knowledge, for the first time considering two important firm characteristics, age and size in this context.

\section{Research hypotheses}

Both firm FP and value have recently attracted academic attention in assessing how the ESG initiatives impact on a firm's prospects (which is also meaningful for its value). For example, Fatemi et al. (2018) find that ESG score strengthens firm value. In the existing literature, one the one hand, firm value is influenced by the cost of ESG undertakings. When the cost is low, a firm could achieve positive results by improving employees' productivity as well as avoiding pollution fines (Barnea \& Rubin, 2010). However, higher utility motivates firm insiders to invest more than value-maximizer levels (as empirically confirmed by (Videras \& Owen, 2006)) and therefore lowers shareholder benefits. Then, since implementing such initiatives across all dimensions is costly, a negative association is expected. The opposing view, on the other hand, highlights the value-enhancing factors of a firm's engagement in ESG. Improvement in operating efficiency (Brammer \& Millington, 2005), capital market benefits (Dhaliwal et al., 2011; Godfrey, 2013) and risk management (Dhaliwal et al., 2012) are among proved benefits of implementing sustainability initiatives. Although both aspects provide a better understanding of the advantages and drawbacks of sustainability in relation to firm value, there is, as yet, no definite outcome for the standing association (Jo \& Harjoto, 2011). Malik (2014) summarizes contributions from both streams and, in agreement with the positive side, acknowledged the value-enhancing possibilities of sustainability engagement. Consequently, the expectation is that ESG has a positive impact on an airline's value. 
H1 For airlines, implementing ESG initiatives have a positive relationship with firm value.

Although the literature has not yet formulate a conclusive, entirely consistent result, regarding the ESG-FP association, a large majority of the conducted research reports a positive link between them (Friede et al., 2015). It is, therefore, generally believed that reasonable implementations of ESG criteria do not necessarily lead to lower returns and financial performance (Hill, 2020). The core aspect of this argument is that contribution to sustainability activities promotes a firm's ethnical identity which leads to a higher stakeholder level of satisfaction and better financial performance (Okafor et al., 2021).

As for airlines, Lee and Park (2010) show that, although ESG activities may decrease short-term FP, they can result in significant positive effects on the long-term FP of air carriers. Consistent with that common belief, this study also proposes as our hypothesis $\mathrm{H} 2$ that there is a positive linkage between ESG-FP. Related studies for the sector have shown that while ESG activities may decrease short-term financial performance, they will cause significant positive effects on the overall long-term FP of air carriers (Lee \& Park, 2010; Lee et al., 2013; Yang \& Baasandorj, 2017). Theodoulidis et al. (2017) pointed out that the differences in the results of similar studies for airlines could be due to disparities in data and analysis methodologies.

\section{H2 For airlines, implementing ESG has a positive relationship with FP.}

Also, empirical contributions to the link between ESG-FP have investigated their role in relationships such as business type (Seo et al., 2015); franchising strategy (Kim \& Lee, 2020); and oil prices (Lee et al., 2013). This study also searches for moderating roles of firm size and age. There are a number of reasons as to why firm size relates to the relationship between ESG-FP. First, larger firms tend to have more available financial resources than do their smaller counterparts (Gupta 1969; D'Amato \& Falivena, 2020). Therefore, they are able to invest more in sustainability projects. Large firms are also considered to have a well-defined strategy and goals to monitor their business and, consequently, are in a better position to handle sustainability projects. Furthermore, a firm's visibility could be considered in this context since more visible firms seem likely to be willing to undertake better sustainability practices due to their public image among shareholders (D'Amato \& Falivena, 2020).

A firm's age is also considered as potential moderator of the relationship (Saeidi et al., 2015). Based on Peloza (2006), the idea is driven from the fact that managers need a kind of insurance to invest in sustainability practices. The introduction of the valuation of sustainability practices offers an insight into the cause-and-effect relationship between ESG-FP and value. On this basis, younger firms are less concerned about their public and social image and are more concentrated on financial performance. Therefore, it is expected that young firms will undertake fewer sustainability-related initiatives (Peloza, 2006; Yang \& Baasandorj, 2017). This view has been supported by the recent empirical work of D'Amato and Falivena (2020), who studied both variables as moderators for ESG implementation and firm value for a sample of Western European companies. They found size and age significantly moderate of the association. The current study considers size and age to be the relevant moderators in ESG-FP and value' relationship. Therefore, $\mathrm{H} 3$ of the study is formulated as below: 
H3 In the moderation relationship of firm financial and firm value with ESG, size and age act as positive moderators.

\section{Methodology}

\subsection{Data}

The data were collected from two sources: the Thomson Reuters Eikon database and the official websites of sampled airlines. Eikon contains sustainability measures in the form of ESG combined scores as well as separate measures for each component. It gathers relevant publicly reported information and formulates metrics based on combination of ten relevant data points reflecting the firm's sustainability activities since 2002 . These data points are grouped into the three ESG dimensions (see "Appendix 1").

These categories are weighted based on an automated and factual logic to calculated the overall score of each dimension and the combined ESG score of the companies (Eikon, 2017). While retrieving ESG data, we found that information is available for only a limited number of airlines (94 firms worldwide) and, even for these, the ESG score does not exist for all years because they started to implement sustainability standards from different years. Therefore, we selected 2009-2019 as longest period possible, leaving us with 38 ESG-rated airlines (see "Appendix 2" for the basic information of sampled airline including country of headquarters, company name, stock code and date of incorporation).

Thomson Reuters also includes the financial data for variables used in this study. However, since we again faced the missing values for financial variables, we referred to airlines' official annual reports as the second source of our data to fill absent values where possible. Before estimating the models, we checked the distributions of explanatory and control variables for normality. We detect outliers and remove them from the dataset (see supplementary file for the step-by-step detailed information about the sources and empirical procedure for filtering and collecting of used data).

\subsection{Variables}

Because the aim of this study is to investigate the consequences of ESG disclosure for airline's FP and value, the group of dependent and independent variables were identified. These variables have been commonly utilized in the relevant literature (see for example Pavlopoulos et al., 2019; Aouadi \& Marsat, 2018; Jo \& Harjoto, 2011; Qureshi et al., 2020). In particular, with reference to the designed framework of factors affection value and financial performance of airlines by Malighetti et al., (2011), study variables are also applied for related research in this context (e.g., Lee et al., 2013; Theodoulidis et al., 2017). In specific, market-to-book ratio is used to find out if a firm's value is affected by ESG. Both market and book values help in the determination of market sentiments for the company. Over the course of time, for firms that are expected to grow and record higher profits, the book value no longer defines the real value as there would be an important gap between book and market value. The well-known Fama-French theory introduced the market-tobook effect as a behavioral anomaly by which firms with high market-to-book ratio (a high stock price relative to book value) tend to be persistently distressed. Conversely, low market-to-book ratio (a low stock price relative to book value) is associated with sustained strong profitability (Fama \& French, 1995). 
Tobin's q is widely used in the literature as representative of FP. There are different formulations of the measure but, as noted by Chung and Pruitt (1994), the yields tend to be similar. We empirically followed the approach by Xie et al. (2019) which defines the Tobin's q as total market value divided by total assets. Thomson Reuter's ESG dimension scores are considered as sustainability performance. Env refers to the degree by which the firm can undertake managerial initiatives to avoid environment risk and take advantage of the opportunities provided in maximizing value for its shareholders. Soc proposed that the firm uses available means to build trust and loyalty to ensure long-term stakeholder benefits. Finally, Gov, is seen as an evaluative tool for the quality of its administration systems and processes.

The current study uses size and age as moderators as well as a set of control variables including return on assets (ROA), leverage and dividend ratio. In line with Yang and Baasandorj (2017), we consider the log of total assets as the firm's size. Likewise, the year in which the airline started doing business is used as the base year for calculating the firm's age. ROA is a proxy of the firm's operating profitability. It is measured as company's operating profit prior to financing costs divided by total assets. Firms with higher profitability are expected to have more chances to invest in sustainability initiatives (Kim \& Lee, 2020; Waddock \& Graves, 1997). Leverage (Lev) is another control variable widely proposed in the literature to control for the capital structure of firms. The theoretical basis for utilizing this ratio arises from trade-off theory which implies that low-growth firms with stable cash flows and tangible assets are likely to use more debt in their capital structure. This characteristic is especially appropriate for the air transport industry which is seen to undertake high average indebtedness, low turnover and negative equity (Pires \& Fernandes, 2012). In accord with Lee et al. (2013), we use the debt ratio (defined as total liabilities over total assets) for a firm's leverage. The dividend ratio is considered as a channel for conveying a firm's wealth to shareholders as well as giving signals to investors regarding a firm's financial status (Moon et al., 2015). Based on Gordon (1959), higher dividends imply a higher firm value. In this sense, we expect a positive relationship between financial performance and dividends.

The current study also uses two initiative dummy variables (1) RepESGs account for the number of years for which the airline has been reporting ESGs and (2) Ctype determines the airline's business model in the full panel. A summary of variables employed is presented in "Appendix 3".

\subsection{Models}

The current study uses panel data for the main analysis. Panel data analysis is a very popular form of longitudinal data in finance in order to investigate the behavior and reaction of firms (e.g., Ferrero-Ferrero et al., 2016; Okafor et al., 2021; Park et al., 2017among others). Depending on diagnostic test outcome, it employs a fixed, random or mixed effect model. These models have also been applied in the literature to investigate the ESG linkage with FP and value. For instance, studies such as (Yang \& Baasandorj, 2017; Qureshi et al., 2020 used fixed effect models, while random effects were employed in Seo et al., 2015; Kim \& Lee, 2020 and Lee et al., 2013). We followed the econometric strategy by Torresreyna (2010) to verify the relevant fit predictor according to the Princeton panel data analysis. On this basis, two tests are conducted: First, Breusch-Pagan's multiplier test (LM-test) was performed to select between Pooled OLS and Panel Data estimation. Second, if panel 
effects existed, the Hausman test was selected between fixed-effects and random-effects models. The test specifies whether significant correlation exists between unobserved specific random effects and the regressors (Yaffee, 2003). The methodology source and data analysis information are presented in "Appendix 4". Based on our above-mentioned hypotheses, we formulated two independent regression equations in the empirical models, including dependent and explanatory variables as follows.

Model I

$$
\begin{aligned}
& \mathrm{MB}_{\mathrm{it}}=\alpha+\beta_{1} \mathrm{Env}_{\mathrm{it}}+\beta_{2} \mathrm{Soc}_{\mathrm{it}}+\beta_{3} \mathrm{Gov}_{\mathrm{it}}+\beta_{4} \mathrm{ROA}_{\mathrm{it}}+\beta_{5} \mathrm{Div}_{\mathrm{it}}+\beta_{6} \mathrm{Lev}_{\mathrm{it}} \\
& +\beta_{7} \text { Size }_{\text {it }}+\beta_{8} \text { Age }_{\text {it }}+\beta_{9} \text { RepESG }_{\text {it }}+\beta_{10} \text { Env }^{*} \text { Size }_{i t}+\beta_{11} \text { Soc }^{*} \text { Size }_{\text {it }} \\
& +\beta_{12} \text { Gov }^{*} \text { Size }_{i t}+\beta_{13} \text { Env }^{*} \text { Age }_{\text {it }}+\beta_{14} \text { Soc }^{*} \text { Age }_{\text {it }}+\beta_{15} \text { Gov }^{*} \text { Age }_{\text {it }}+\varepsilon_{\text {it }}
\end{aligned}
$$

Model II

$$
\begin{aligned}
& T Q_{\mathrm{it}}=\alpha+\beta_{1} \mathrm{Env}_{\mathrm{it}}+\beta_{2} \mathrm{Soc}_{\mathrm{it}}+\beta_{3} \mathrm{Gov}_{\mathrm{it}}+\beta_{4} \mathrm{ROA}_{\mathrm{it}} \\
& +\beta_{5} \operatorname{Div}_{\mathrm{it}}+\beta_{6} \operatorname{Lev}_{\mathrm{it}}+\beta_{7} \mathrm{Size}_{\mathrm{it}}+\beta_{8} \mathrm{Age}_{\mathrm{it}} \\
& +\beta_{9} \operatorname{RepESG}_{\mathrm{it}}+\beta_{10} \mathrm{Env}^{*} \mathrm{Size}_{\mathrm{it}}+\beta_{11} \text { Soc }^{*} \mathrm{Size}_{\mathrm{it}} \\
& +\beta_{12} \mathrm{Gov}^{*} \mathrm{Size}_{\mathrm{it}}+\beta_{13} \text { Env }^{*} \mathrm{Age}_{\mathrm{it}}+\beta_{14} \mathrm{Soc}^{*} \mathrm{Age}_{\mathrm{it}} \\
& +\beta_{15} \mathrm{Gov}^{*} \mathrm{Age}_{\mathrm{it}}+\varepsilon_{\mathrm{it}}
\end{aligned}
$$

A number of robustness tests have been proposed before executing panel regression analysis. This is due to the problems that these models encounter such as outliers (biasing the regression slope) and autocorrelation (Yaffee, 2003). We removed outliers and, to identify potential endogeneity among variables, we derived the correlation matrix and variance inflation factor (VIF). A correlation coefficient measures the strength and direction of a linear relationship between two variables. Table 1 summarizes the correlation matrix of the variables employed in this study. There is a relatively moderate correlation between the ESGs. In particular, the social and environment variables have the highest correlation. Excepting these two, the absolute values for the other variables are under 0.5 , indicating an absence of significant. As for the VIF, Table 2 shows that since all values are smaller than 10 , we may conclude that our data do not suffer from multicollinearity.

\section{Empirical results}

\subsection{Descriptive analysis}

Summary statistics for the research variables are presented in Table 3 . These data are based on an illustrative review of 4279 firm-year observations for our 38 airlines. The marketto-book ratio ranges from 0.00 to 3.98 , with a mean value of 1.45 . This means that airline stock is expensive, and the current market value of airline assets is different from the balance sheet records. Another reason for this high ratio is because of airlines' intangible assets, which is normally ignored in book value. Tobin's q is distributed between 0.00 and 4.06 , with a mean and standard deviation of 0.5 . The high values for the sampled airlines indicate that their replacement costs are greater than the value of their assets. Return on assets (ROA) is relatively low with a mean value of 0.06 , implying the sampled firms' inefficient performance in converting the invested capital into operating profit. As for the 


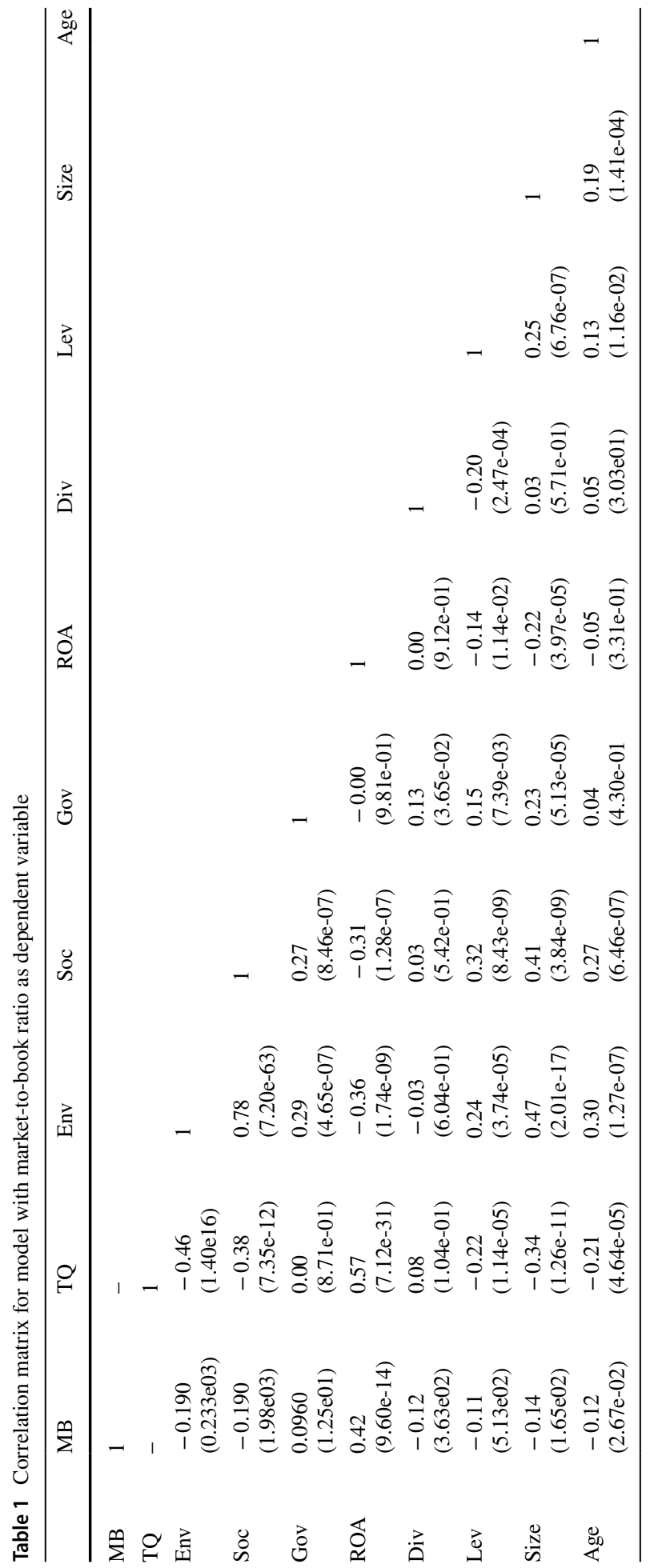


Table 2 Variance inflation factor

\begin{tabular}{|c|c|c|c|c|c|c|c|c|c|}
\hline Env & Soc & Gov & ROA & Div & Lev & Size & Age & Ctype & RepESG \\
\hline \multicolumn{10}{|c|}{ Panel with market-to-book ratio } \\
\hline 2.39 & 1.87 & 1.17 & 1.14 & 1.05 & 1.11 & 1.90 & 1.38 & 1.60 & 1.94 \\
\hline \multicolumn{10}{|c|}{ Panel with Tobin's $q$} \\
\hline 2.36 & 1.93 & 1.24 & 1.13 & 1.04 & 1.15 & 1.78 & 1.45 & 1.93 & 2.05 \\
\hline
\end{tabular}

Table 3 Summary of descriptive statistics

\begin{tabular}{lcccccccccl}
\hline Var/Index & MB & TQ & \multicolumn{1}{c}{ Env } & \multicolumn{1}{l}{ Soc } & \multicolumn{1}{l}{ Gov } & \multicolumn{1}{c}{ Lev } & ROA & Div & Size & Age \\
\hline Mean & 1.45 & 0.5 & 42.06 & 50.82 & 52.18 & 0.70 & 0.06 & 0.16 & 18.237 & 40.16 \\
Median & 1.27 & 0.3 & 42.48 & 51.86 & 54.54 & 0.73 & 0.03 & 0.01 & 15.500 & 44 \\
Max & 3.98 & 4.6 & 95.36 & 79.88 & 96.07 & 1.20 & 0.91 & 3.29 & 64.529 & 100 \\
Min & 0.00 & 0.00 & 0.21 & 4.24 & 7.33 & 0.00 & -0.06 & 0.00 & 5.092 & 1 \\
Std. de & 0.79 & 0.5 & 21.35 & 20.28 & 23.52 & 0.23 & 0.11 & 0.27 & 14.115 & 25.93 \\
Skewness & 0.76 & 3.2 & -0.39 & -0.22 & -0.03 & -0.71 & 4.42 & 4.85 & 0.91 & 0.30 \\
Kurtosis & 0.41 & 15.6 & -0.91 & -0.57 & -1.02 & 1.37 & 22.76 & 45.85 & 0.29 & -1.07 \\
\hline
\end{tabular}

ESGs, the overall means is 48.35 which is considered an acceptable performance level. The Gov dimension has the highest average score of 50.82, followed by the Soc with 50.82. This means that, among sustainability measures, initiatives related to board members and executives are considered more often by the airlines. The mean score on the environmental variable is 42.06 , showing a weakness in airlines' efforts to integrate policies and systems for environmental management.

\subsection{The influence of ESG on firm value}

As shown in Table 4, the results indicate that the Gov dimension is statistically significant at the 5 percent level, supporting hypothesis H1. This is due to the tangible merit underlying Gov practices such as launching responsible leadership and independent supervision to guarantee maximizing shareholder benefits as well as implementing a sustainability reporting strategy. However, the Soc and Env dimensions are found to be insignificant but negative. This implies that a firm's efforts to build public image and eco-friendly initiatives such as utilizing re-usable resources, innovation and reduce emissions decrease their market-to-book ratio and could potentially pave the way toward financial distress. In particular, only if a firm's allocation method to these activities creates human and social capital and builds intangible assets by greater environmental efficiency, can one expect the firm to be rewarded with higher market-to-book ratio (Serafeim, 2020). Therefore, H1 is not supported from these two dimensions. These result are inconsistent with Qureshi et al. (2020) which, for a set of 812 European firms, finds environmental and social disclosures to be more relevant to value than the governance score. Regarding the coefficients of the control variables, leverage and size both are negative and significant at the $10 \%$ level of confidence. 
Table 4 Empirical results for market-to-book ratio models

\begin{tabular}{|c|c|c|c|}
\hline Variables & Coefficients & $t$-value & $p$-value \\
\hline Panel I & Main effect model & Fixed effects & \\
\hline Env & -0.00308120 & -0.8063 & 0.421483 \\
\hline Soc & -0.00069569 & -0.1889 & 0.850420 \\
\hline Gov & 0.00802102 & 2.5296 & $0.012560 *$ \\
\hline $\mathrm{ROA}$ & -0.98565469 & -0.8566 & 0.393189 \\
\hline Lev & -0.92669272 & -1.9175 & 0.057270 \\
\hline Div & -0.11849342 & -0.5855 & 0.559172 \\
\hline Size & -0.41515995 & -1.9099 & 0.058251 \\
\hline Age & -0.41499220 & -1.4294 & 0.155182 \\
\hline RepESG & 0.34945381 & 3.0003 & $0.003209 * *$ \\
\hline Panel II & Full panel & Fixed effects & \\
\hline Env & 0.0971888 & 2.0265 & $0.044757 *$ \\
\hline Soc & -0.1352667 & -2.0201 & $0.045423 *$ \\
\hline Gov & 0.0909941 & 2.1965 & $0.029827 *$ \\
\hline ROA & -0.5448529 & -0.4662 & 0.641823 \\
\hline Lev & -1.1126794 & -2.1668 & $0.032070 *$ \\
\hline Div & -0.0961579 & -0.4717 & 0.637907 \\
\hline Size & -0.2863860 & -0.8581 & 0.392395 \\
\hline Age & -0.1547649 & -0.3313 & 0.740933 \\
\hline RepESG & 0.3248332 & 2.7406 & $0.006995 * *$ \\
\hline Env*size & -0.0122752 & -2.2468 & $0.026338 *$ \\
\hline Soc*size & 0.0129358 & 1.8771 & 0.062745 \\
\hline Gov*size & -0.0051428 & -1.2760 & 0.204229 \\
\hline Env*age & 0.0051986 & 0.9077 & 0.365719 \\
\hline Soc*age & 0.0025663 & 0.3422 & 0.732717 \\
\hline Gov*age & -0.0093839 & -1.8204 & 0.070991 \\
\hline Panel III & Full services & Fixed effects & \\
\hline Env & 0.1752520 & 1.9949 & $0.04864 *$ \\
\hline Soc & -0.1156538 & -1.3238 & 0.18845 \\
\hline Gov & 0.0692412 & 1.2244 & 0.22355 \\
\hline ROA & 0.4738201 & 0.4527 & 0.65168 \\
\hline Lev & -1.3578937 & -2.5580 & $0.01196 *$ \\
\hline Div & 0.0151438 & 0.0588 & 0.95324 \\
\hline Size & 0.2531895 & 0.5092 & 0.61166 \\
\hline Age & -0.5418961 & -0.9302 & 0.35442 \\
\hline RepESG & 0.2737154 & 2.5739 & $0.01145 *$ \\
\hline Env*size & -0.0175598 & -2.1889 & $0.03082 *$ \\
\hline Soc*size & 0.0126794 & 1.5038 & 0.13564 \\
\hline Gov*size & -0.0074265 & -1.6241 & 0.10735 \\
\hline Env*age & 0.0015910 & -0.2304 & 0.81823 \\
\hline Soc*age & -0.0023289 & -0.2861 & 0.77538 \\
\hline Gov*age & 0.0010822 & 0.1662 & 0.86833 \\
\hline Panel IV & Low costs & Pooling model & \\
\hline Env & 0.238287 & 1.1841 & 0.253680 \\
\hline Soc & -0.546542 & -3.0403 & $0.007796 * *$ \\
\hline Gov & 0.024657 & 0.2469 & 0.808123 \\
\hline
\end{tabular}


Table 4 (continued)

\begin{tabular}{llll}
\hline Variables & Coefficients & $t$-value & $p$-value \\
\hline ROA & -1.230319 & -0.4633 & 0.649419 \\
Lev & -0.149126 & -0.2158 & 0.831868 \\
Div & 0.018191 & 0.0532 & 0.958253 \\
Size & -0.578720 & -0.9386 & 0.361868 \\
Age & -1.077727 & -0.5432 & 0.594484 \\
RepESG & -0.113856 & -0.5731 & 0.574542 \\
Env*size & -0.017367 & -0.6801 & 0.506157 \\
Soc*size & 0.043819 & 1.5703 & 0.135899 \\
Gov*size & 0.002946 & 0.2801 & 0.783027 \\
Env*age & -0.026147 & -0.8420 & 0.412194 \\
Soc*age & 0.056838 & 0.9551 & 0.353752 \\
Gov*age & -0.021053 & -1.0811 & 0.295688 \\
\hline
\end{tabular}

Signif. codes '***'if $p$-value $<0.001$; '**'if $p$-value $<0.01$; '*' if $p$-value $<0.05$; ' ' if $p$-value $<0.1$

To seek a moderation role of size and age in the existing association between sustainability initiatives and firm value, we include interaction terms between the three Env, Soc and Gov dimensions of ESG and these two variables in panels II, III and IV. Specifically, when interaction terms are added to the models, it is evident that they become considerably different in their coefficients and significances. Despite inconsistencies in the direction, we find that the size factor moderated the relationship between sustainability measures and firm value for the full set and full-service airline panels. Therefore, the relationship is significantly moderated by the size factor which supports H3. The direction for both Env and Gov dimensions is negative implying that bigger airlines' efforts to improve their value through these will have negative results. From the Gov dimension, this outcome is confirmed since, for the low-cost panel which is made of relatively smaller firms in comparison with full-service airlines, the sign becomes positive. The interaction between environment and size across the panels is negative and significant (except for Low-cost panel), which means that the relationship between environmental initiatives and airline value is moderated by company size. For bigger airlines (full services and the full set of airlines), it is significant and negative meaning that investment in Env activities for these airlines may not be met with an increase in the market-to-book ratio.

Regarding the moderation impact of company age on the relationship between sustainability performance and firm value, we find statistically significant results only for environmental initiatives in the panel involving the full set of airlines. The moderator influences sustainability initiatives in different directions across the panels. This direction is similar for full-panel and full-service airlines since 27 out of 38 sampled airlines are categorized as full costs. For example, the weighted moderator interaction Env*age is positive for in full panel and full-service panels which is consistent with the view that bigger and older firms have more resources available to contribute to eco-friendly activities. Overall, age is apparently not a significant moderator of the relationship between firm value and its sustainability engagement. 


\subsection{The influence of ESG on FP}

Likewise, the results of panel with Tobin's q as dependent variable are presented in Table 5. This panel first tests $\mathrm{H} 2$ which predicts that FP is more likely to increase if firm undertake ESGs. The results show that both Env and Soc activities are positively and significantly (for the social dimension) linked with FP. The H2 hypothesis therefore gains support in both dimensions. Finding a positive influence for Env and Soc is probable because both initiatives are directly related to the firm's operation and improvement in either could decrease the cost involved in their operations which would consequently enhance their FP. Our results for the Env dimension score are consistent with Duque-Grisales and AguileraCaracuel (2019) who also find that a firm's effort to avoid environment risk will be positively rewarded by a higher FP. Also, the results of the social dimension are in line with Qiu et al. (2016); Xie et al. (2019) and Yang and Baasandorj (2017) who also find social disclosure as a driver of financial efficiency.

Gov is found to be negative. This reverse influence of the association between ESG-FP implies that a firm's expenses for setting board and CSR strategy for airlines will not be compensated by a better FP. As in the models for market-to-book ratio as a dependent variable, size is also lower than 0.1. Together with lev, div and age, in this main effect panel it negatively affects the FP. The RepESG dummy variable is also similar to the market-tobook ratio panel in being positive and significant, which could be interpreted as saying that the greater the number of years firms have been participating in ESG initiatives, the greater the benefit they are obtaining from these activities.

Considering the results for interaction effects of size and age on the association, the results are similar with the market-to-book ratio models. On the one hand, the size factor is found to be a significant moderator for ESG-FP of sampled firms. This indicates that, before undertaking sustainability initiatives, airlines' total assets must be evaluated (especially if the considered sustainability activity is categorized as in the Env dimension). For this ESG sub-factor, size significantly decreases the FP regardless the type of airline. For both big and small companies, it is expected that this moderator decreases the FP for relevant airlines. For bigger companies, the Gov activities negatively influence the association between sustainability measures and FP while for smaller firms (low costs) it found to be a positive moderator of the association. This means that smaller airlines are suggested to invest in leadership and shareholder maximizing initiatives if they consider the sustainability effects. Size is also found to be not a moderator in the case of societal initiatives. Overall, since for Env and Gov dimensions, the ESG-financial performance relationship is apparently significant (in both big and small airline sets), we consider size as moderator which supports H3. Finally, regarding age as moderator, we reached the opposite conclusion. Specifically, it is found to be non-significant for all three ESG dimensions across the panels (but with disperse signs). Given this, it seems that age is not a major factor in the relationship between a firm's performance and sustainability performances. 
Table 5 Empirical results for Tobin's q model

\begin{tabular}{|c|c|c|c|}
\hline Variables & Coefficients & $t$-value & $p$-value \\
\hline Panel I & Main effect model & Fixed Effects & \\
\hline Env & $8.4086 \mathrm{e}-05$ & 0.0195 & 0.984505 \\
\hline Soc & $7.5855 \mathrm{e}-03$ & 1.7761 & 0.077508 \\
\hline Gov & $-1.4629 \mathrm{e}-03$ & -0.4278 & 0.669360 \\
\hline ROA & $1.2236 \mathrm{e}-01$ & 0.0916 & 0.927092 \\
\hline Lev & $-4.3003 e-01$ & -0.7684 & 0.443296 \\
\hline Div & $-1.6223 \mathrm{e}-01$ & -0.7253 & 0.469252 \\
\hline Size & $-8.0518 \mathrm{e}-01$ & -3.2909 & $0.001216^{* *}$ \\
\hline Age & $-1.3315 \mathrm{e}-01$ & -0.3870 & 0.699261 \\
\hline RepESG & $3.0252 \mathrm{e}-01$ & 2.5479 & $0.011729 *$ \\
\hline Panel II & Full panel & Fixed effects & \\
\hline Env & 0.1125035 & 2.0665 & $0.04036 *$ \\
\hline Soc & 0.0137444 & 0.1930 & 0.84722 \\
\hline Gov & 0.0519313 & 1.2873 & 0.19983 \\
\hline ROA & 0.5825599 & 0.4479 & 0.65481 \\
\hline Lev & -0.5196154 & -0.9276 & 0.35500 \\
\hline Div & -0.3092335 & -1.4020 & 0.16283 \\
\hline Size & 0.1313367 & 0.3576 & 0.72111 \\
\hline Age & -0.1214286 & -0.2587 & 0.79621 \\
\hline RepESG & 0.2513745 & 2.1240 & $0.03518 *$ \\
\hline Env*size & -0.0150643 & -2.4733 & $0.01441 *$ \\
\hline Soc*size & 0.0010252 & 0.1380 & 0.89042 \\
\hline Gov*size & -0.0063285 & -1.5635 & 0.11987 \\
\hline Env*age & 0.0088455 & 1.3878 & 0.16709 \\
\hline Soc*age & -0.0045957 & -0.5702 & 0.56934 \\
\hline Gov*age & 0.0015105 & 0.2926 & 0.77021 \\
\hline Panel III & Full services & Fixed effects & \\
\hline Env & 0.10822037 & 1.3965 & 0.1650222 \\
\hline Soc & 0.04059882 & 0.4504 & 0.6531605 \\
\hline Gov & 0.16789143 & 3.3874 & $0.0009419 * * *$ \\
\hline ROA & 0.41422300 & 0.3586 & 0.7204880 \\
\hline Lev & -1.20434211 & -2.1089 & $0.0369353 *$ \\
\hline Div & -0.75507475 & -2.7036 & $0.0078068 * *$ \\
\hline Size & 1.27326622 & 2.8093 & $0.0057581 * *$ \\
\hline Age & -0.28883805 & -0.5518 & 0.5820759 \\
\hline RepESG & 0.26857797 & 2.2805 & $0.0242571 *$ \\
\hline Env*size & -0.01221760 & -1.7020 & 0.0912196 \\
\hline Soc*size & 0.00435026 & -0.5059 & 0.6137896 \\
\hline Gov*size & -0.01594252 & -3.6900 & $0.0003324 * * *$ \\
\hline Env*age & 0.00346161 & 0.4612 & 0.6454714 \\
\hline Soc*age & -0.00019973 & -0.0231 & 0.9816223 \\
\hline Gov*age & -0.00465805 & -0.7082 & 0.4801546 \\
\hline Panel IV & Low costs & Fixed effects & \\
\hline Env & 0.7660558 & 2.5750 & $0.019074 *$ \\
\hline Soc & -0.0450244 & -0.1574 & 0.876670 \\
\hline Gov & -0.6002875 & -3.1696 & $0.005305 * *$ \\
\hline
\end{tabular}


Table 5 (continued)

\begin{tabular}{llll}
\hline Variables & Coefficients & $t$-value & $p$-value \\
\hline ROA & 1.5733169 & 0.4182 & 0.680742 \\
Lev & 1.4229825 & 0.9363 & 0.361527 \\
Div & -0.1458301 & -0.3028 & 0.765548 \\
Size & 0.3434971 & 0.2675 & 0.792131 \\
Age & -4.4489506 & -1.1341 & 0.271623 \\
RepESG & 0.3344415 & 0.7138 & 0.484509 \\
Env*size & -0.0669633 & -2.0948 & 0.050603 \\
Soc*size & -0.0240344 & -0.7330 & 0.473023 \\
Gov*size & 0.0672145 & 2.6070 & $0.017834 *$ \\
Env*age & -0.0629068 & -1.2866 & 0.214529 \\
Soc*age & 0.0932622 & 1.4922 & 0.152971 \\
Gov*age & 0.0043871 & 0.1080 & 0.915161 \\
\hline
\end{tabular}

Signif. codes '***'if $p$-value $<0.001$; '**'if $p$-value $<0.01$; '*' if $p$-value $<0.05$; ' ' if $p$-value $<0.1$

\subsection{Robustness test}

In addition to the main analysis based on the econometric approach defined in Sect. 3.3, this study also performs a sensitivity analysis to check the robustness of the results. To do so, we follow (Moneva et al., 2020; Song et al., 2021) in estimating the alternative models with different time periods to estimate changes from the baseline condition. Specifically, we estimate the models for the limited part of the dataset which contains only the balanced sample (Moneva et al., 2020). We run the regression models for years 2016-2019 where almost all the data points were available (during this period, there were only 77 missing values out of the 1976 observations - these were filled by the mean of each entity). The results of the model for both market-to-book ratio and Tobin's q as dependent variables are presented in Tables 6 and 7.

As can be seen from the above models, although there are some differences in coefficients and influence directions, in general the results for both models led to similar yield estimations. The results are especially consistent for models with full-service and low-cost carrier's data.

\section{Discussion}

Our study first aimed at testing the separate impacts of ESG activities on firm value and FP. Secondly, it aimed to uncover the moderating effect of firm size and age in the linkage between them. We employed data from 38 airlines retrieved from Eikon for the 2009-2019 period. The sample is broken down based on the firms' business models: full-service and low-cost carriers. The findings are discussed in this section. 
Table 6 Empirical results for panel with market-to-book ratio models

\begin{tabular}{|c|c|c|c|}
\hline Variables & Coefficients & $t$-value & $p$-value \\
\hline Panel I & Main effect model & Fixed effects & \\
\hline Env & 0.00688604 & 1.7758 & 0.07867 \\
\hline Soc & -0.00527636 & -1.3750 & 0.17207 \\
\hline Gov & -0.00308728 & -1.2784 & 0.20391 \\
\hline ROA & -1.80439855 & -1.7085 & 0.09051 \\
\hline Lev & -1.03026792 & -2.2857 & $0.02428 *$ \\
\hline Div & 0.36675533 & 2.0948 & $0.03859 *$ \\
\hline Size & -0.10092030 & -0.7059 & 0.48181 \\
\hline Age & -0.50423819 & -1.1105 & 0.26931 \\
\hline RepESG & 0.00064202 & 0.0058 & 0.99542 \\
\hline Panel II & Full panel & Fixed effects & \\
\hline Env & -0.06460538 & -1.2282 & 0.22227 \\
\hline Soc & 0.04327144 & 1.3054 & 0.19477 \\
\hline Gov & 0.03942618 & 2.2220 & $0.02856^{*}$ \\
\hline ROA & -1.68894024 & -1.5845 & 0.11628 \\
\hline Lev & -1.06429765 & -2.3573 & $0.02038^{*}$ \\
\hline Div & 0.32133421 & 1.8265 & 0.07079 \\
\hline Size & -0.17113112 & -0.8922 & 0.37444 \\
\hline Age & 0.33740661 & 0.5826 & 0.56148 \\
\hline RepESG & 0.02214816 & 0.1925 & 0.84773 \\
\hline Env*size & 0.00509383 & 0.9691 & 0.33486 \\
\hline Soc*size & -0.00379779 & -1.0112 & 0.31436 \\
\hline Gov*size & -0.00044559 & -0.2819 & 0.77863 \\
\hline Env*age & 0.00666247 & 1.3803 & 0.17060 \\
\hline Soc*age & -0.00379362 & -0.6191 & 0.53728 \\
\hline Gov*age & -0.01033211 & -2.3036 & $0.02333^{*}$ \\
\hline Panel III & Full services & Fixed effects & \\
\hline Env & -0.05382596 & -0.4981 & 0.6200805 \\
\hline Soc & -0.00884222 & -0.1869 & 0.8522939 \\
\hline Gov & -0.01264583 & -0.4462 & 0.6569456 \\
\hline ROA & -3.86484930 & -2.5517 & $0.0130433^{*}$ \\
\hline Lev & -2.66991599 & -3.4858 & $0.0008774 * * *$ \\
\hline Div & 0.18437234 & 0.7471 & 0.4576324 \\
\hline Size & -0.51669972 & -1.1781 & 0.2429880 \\
\hline Age & -1.85125813 & -1.3099 & 0.1947638 \\
\hline RepESG & 0.14541182 & 0.8346 & 0.4069653 \\
\hline Env*size & 0.00096779 & 0.1199 & 0.9049303 \\
\hline Soc*size & 0.00151939 & 0.3481 & 0.7288494 \\
\hline Gov*size & 0.00089523 & 0.4891 & 0.6263582 \\
\hline Env*age & 0.01265428 & 1.0761 & 0.2858103 \\
\hline Soc*age & -0.00258308 & -0.3088 & 0.7584748 \\
\hline Gov*age & -0.00019108 & -0.0273 & 0.9782710 \\
\hline Panel IV & Low costs & Fixed effects & \\
\hline Env & 0.0632933 & 0.4713 & 0.64310 \\
\hline Soc & -0.0465458 & -0.3741 & 0.71267 \\
\hline Gov & -0.1059357 & -1.2740 & 0.21886 \\
\hline
\end{tabular}


Table 6 (continued)

\begin{tabular}{llll}
\hline Variables & Coefficients & $t$-value & $p$-value \\
\hline ROA & -0.9166737 & -0.4196 & 0.67972 \\
Lev & -0.4803367 & -0.5953 & 0.55902 \\
Div & 0.4365506 & 1.5749 & 0.13270 \\
Size & 0.0468763 & 0.0961 & 0.92448 \\
Age & -0.1161723 & -0.0719 & 0.94351 \\
RepESG & -0.2937250 & -1.3687 & 0.18792 \\
Env*size & -0.0150544 & -1.0253 & 0.31879 \\
Soc*size & 0.0061474 & 0.3787 & 0.70936 \\
Gov*size & 0.0097933 & 1.1661 & 0.25880 \\
Env*age & 0.0161772 & 2.1761 & $0.04311 *$ \\
Soc*age & 0.0054048 & 0.3383 & 0.73908 \\
Gov*age & 0.0053013 & 0.5087 & 0.61713 \\
\hline
\end{tabular}

Signif. codes '***'if $p$-value $<0.001$; '**'if $p$-value $<0.01$; '*' if $p$-value $<0.05$; ' ' if $p$-value $<0.1$

\subsection{Main effects of ESGs on firm value and financial performance}

As the initial purpose of this study, we check whether ESG activities drive the firm value and FP for firms operating in the airline industry. In regard to firm value, the empirical result for the Gov dimension supports the stakeholder theory which suggests that an airline's contribution to this initiative could act as a value driver for the firm. In particular, it implies that activities related to the distribution of rights and responsibilities among board of directors and stakeholders as firm participants and ensuring the firm's accountability could create value for a firm. The finding of Duque-Grisales and Aguilera-Caracuel (2019) for a negative effect of Gov differs from our result. In contrast, environmental and social disclosures negatively change market-to-book ratio indicating that investing in these dimensions leads to a decrease in its value. This outcome is not consistent with Qureshi et al. (2020) and Xie et al. (2019) who find that both Env and Soc are relevant and have a positive relationship with firm value.

As for the Tobin's q model, the results of a fixed-effects model indicate a positive sign for Env and Soc sub-factors which is consistent with several hypothetical frameworks for the ESG-FP linkage. On this basis, based on both the stakeholder theory and the slack resource theory, allocating available resources to eco-friendly and societal projects will be rewarded by a higher firm FP in the airline industry. Therefore, the use of renewable resources, innovation and reducing emission from Env perspective, as well as an effort to improve human rights or decrease demographic discrimination, training programs and product responsibility in its social aspect, all bring more returns on invested funds. These findings are in line with the research from the Theodoulidis et al. (2017) and Lee and Park (2010) carried out for the same industry. They are, however, inconsistent with results from a set of 104 multinational firms examined by Duque-Grisales and Aguilera-Caracuel (2019) which supports the view that industry characteristics probably affect the relationship between ESG-FP, and therefore, the outcome might vary across industries (Theodoulidis et al., 2017). Considering control variables in both models, we see that leverage, dividend ratio, size and age all negatively influence the association between ESG disclosure and FP. 
Table 7 Empirical results for panel with Tobin's q models

\begin{tabular}{|c|c|c|c|}
\hline Variables & Coefficients & $t$-value & $p$-value \\
\hline Panel I & Main effect model & Random effects & \\
\hline Env & 0.0096855 & 1.9107 & 0.05604 \\
\hline Soc & -0.0067958 & -1.3123 & 0.18940 \\
\hline Gov & -0.0071574 & -2.2044 & $0.02749 *$ \\
\hline ROA & 3.1911119 & 2.1768 & $0.02950^{*}$ \\
\hline Lev & -0.5586963 & -1.1268 & 0.25982 \\
\hline Div & 0.0893456 & 0.3563 & 0.72165 \\
\hline Size & 0.0736137 & 0.7813 & 0.43464 \\
\hline Age & 0.2265869 & 1.2389 & 0.21537 \\
\hline RepESG & -0.0885053 & -0.7891 & 0.43006 \\
\hline Panel II & Full panel & Random effects & \\
\hline Env & $-5.5516 \mathrm{e}-02$ & -1.1479 & 0.25102 \\
\hline Soc & $4.1989 \mathrm{e}-02$ & 1.0861 & 0.27742 \\
\hline Gov & $4.2552 \mathrm{e}-02$ & 1.7539 & 0.07945 \\
\hline ROA & $3.5679 \mathrm{e}+00$ & 2.4218 & $0.01545^{*}$ \\
\hline Lev & $-6.7746 e-01$ & -1.3095 & 0.19037 \\
\hline Div & $3.7737 e-02$ & 0.1502 & 0.88061 \\
\hline Size & $1.2553 \mathrm{e}-01$ & 0.6986 & 0.48482 \\
\hline Age & $8.9386 \mathrm{e}-01$ & 1.9149 & 0.05550 \\
\hline RepESG & $-5.4435 \mathrm{e}-02$ & -0.4593 & 0.64599 \\
\hline Env*size & $4.9730 \mathrm{e}-03$ & 1.0014 & 0.31665 \\
\hline Soc*size & $-5.4363 e-03$ & -1.1886 & 0.23459 \\
\hline Gov*size & $-1.3115 e-05$ & -0.0059 & 0.99530 \\
\hline Env*age & $5.2161 \mathrm{e}-03$ & 0.7720 & 0.44010 \\
\hline Soc*age & $2.1994 \mathrm{e}-04$ & 0.0264 & 0.97895 \\
\hline Gov*age & $-1.3298 \mathrm{e}-02$ & -2.3101 & $0.02088^{*}$ \\
\hline Panel III & Full services & Random effects & \\
\hline Env & 0.00491784 & 0.0885 & 0.9294 \\
\hline Soc & -0.01377783 & -0.3026 & 0.7622 \\
\hline Gov & 0.02112648 & 0.7960 & 0.4260 \\
\hline ROA & 0.73813062 & 0.3944 & 0.6933 \\
\hline Lev & -0.46835998 & -0.6047 & 0.5454 \\
\hline Div & -0.37789391 & -1.2406 & 0.2148 \\
\hline Size & 0.02966399 & 0.1718 & 0.8636 \\
\hline Age & 0.30630260 & 0.4620 & 0.6440 \\
\hline RepESG & -0.03927320 & -0.2869 & 0.7742 \\
\hline Env*size & -0.00168502 & -0.3137 & 0.7537 \\
\hline Soc*size & 0.00027179 & 0.0623 & 0.9504 \\
\hline Gov*size & 0.00013341 & 0.0651 & 0.9481 \\
\hline Env*age & 0.00654051 & 0.7228 & 0.4698 \\
\hline Soc*age & 0.00159158 & 0.1617 & 0.8715 \\
\hline Gov*age & -0.00848747 & -1.2531 & 0.2102 \\
\hline Panel IV & Low costs & Fixed effects & \\
\hline Env & -0.1263421 & -0.5255 & 0.60565 \\
\hline Soc & -0.1102380 & -0.4950 & 0.62660 \\
\hline Gov & -0.2399777 & -1.6122 & 0.12432 \\
\hline
\end{tabular}


Table 7 (continued)

\begin{tabular}{llll}
\hline Variables & Coefficients & $t$-value & $p$-value \\
\hline ROA & 7.6179557 & 1.9480 & 0.06718 \\
Lev & -1.3706229 & -0.9489 & 0.35521 \\
Div & -0.5519194 & -1.1122 & 0.28069 \\
Size & -1.0537136 & -1.2070 & 0.24304 \\
Age & 3.8613508 & 1.3342 & 0.19877 \\
RepESG & -0.5204036 & -1.3546 & 0.19230 \\
Env*size & 0.0020548 & 0.0782 & 0.93855 \\
Soc*size & 0.0100679 & 0.3464 & 0.73304 \\
Gov*size & 0.0371625 & 2.4718 & $0.02365 *$ \\
Env*age & 0.0226712 & 1.7035 & 0.10567 \\
Soc*age & 0.0121706 & 0.4255 & 0.67552 \\
Gov*age & -0.0175407 & -0.9403 & 0.35953 \\
\hline
\end{tabular}

Signif. codes '***'if $p$-value $<0.001$; '**' if $p$-value $<0.01$; '*' if $p$-value $<0.05$; ' 'if $p$-value $<0.1$

\subsection{Moderating role of size and age}

The empirical results show that firm size significantly moderates the relationship between sustainability disclosure and dependent variables. However, the moderation direction is different across panels, depending on the type of sustainability undertakings, which gains clear support from the argument by López-Pérez et al. (2017) to the effect that a different slope in the association is likely for large and small firms. We find that the interaction term between size and both Env and Gov dimensions is significant and negative for full-services panel. This result is consistent with the view suggesting that size could play a key role in the relationship between ESG and firm value (Udayasankar, 2008); however, it goes against the argument suggesting that company size positively influence the resources for providing ESG (Drempetic et al., 2019). This set of airlines is considered as bigger size firms as opposed to low-cost carriers having relatively smaller total assets and therefore being smaller in size. The same finding was found for the panel covering the full set of airlines where, for our dependent variables, both Env and Gov (in most cases) are negative and significant. This finding also goes against the general sustainability viewpoint which considers firms with relatively higher total assets, and therefore bigger size, are likely to sloped positively. In contrast, we find a consistent interaction sign for the Env category in the low-cost panel which supports the sustainability hypothesis that smaller firms may not contribute to sustainability as much as do their bigger counterparts (Waddock \& Graves, 1997). The practical interpretation of this finding is that managers of low-cost airlines may expect negative market-to-book ratio and financial return if they decide to invest in environmentally related initiatives.

The current study also tests the potential moderating role of firm age. Full-service carriers are considered as older firms in that the low-cost idea is relatively new in the 
airline business. Our findings show that, although statistically insignificant (except for governance dimension in full panel), it somehow moderates the linkage of ESG initiatives and the study dependent variables. The interesting detection for age is the direction of its interaction term which, in most cases, is found to be consistent with expectations from the sustainability hypothesis. As a notable example, for both market-to-book ratio and Tobin's q estimations, the direction of interaction term for environment disclosure is positive (negative) for full-service (low-cost) carriers. This is consistent with the idea that older (younger) firms have positive (negative) slope with more (less) collaboration in sustainability activities (Withisuphakorn \& Jiraporn, 2015). Moreover, this result supports the business strategy of low-cost airlines in which the main focus is on tangible cost reduction operations (Seo et al., 2015). From this viewpoint, lowcost airlines investment on environmental activities probably would not offset the cost involved in these operations, although they do for full-service carriers.

\section{Conclusion}

The underlying motivation of the research topic is to analyze the impacts of ESG on FP and value in the airline industry. Although the topic has been widely investigated in recent scientific literature across industries, the contributions in an air transport context have been limited. To address the gap, this study aims at providing insights on the relevance of implementing ESGs for managers and executives of airlines who plan to improve financial efficiency. We further investigate whether firm size and age might play a moderating role in this association. The set of data from 38 airlines retrieved from Eikon for years 2009-2019. Our empirical results suggest that ESG initiatives affect firm's market-to-book ratio and FP in opposite directions. For our sampled airlines, we find that the outcome for funding social and environmental operations would be a decline in firm's market-to-book ratio, but increase in its Tobin's q. This suggests that, if managers are considering investing in these sub-factors to enhance financial performance, they may expect a low market-to-book ratio for their equity. We also find that the moderating role of firm size in the relationship between ESG and dependent variables is significant. Firm age may also overlap the association and influence the firm's strategic decisions related with sustainability initiatives, but, in general, we did not find it to be a significant moderator.

Our results are extremely relevant to both the academic literature and to airline executives. From an academic perspective, the study contributes to an advance in the association between ESG and FP in tourism and airline literature. Here, we first provide empirical evidence for both stakeholder theory and resource-based theory which is based on both approaches, implementing sustainability criteria have implications for FP. Also, since researchers in the field have paid relatively little attention to investigating moderator variables, we attempted to fill the gap by empirically testing the potential roles of firm size and age. Therefore, our findings could be taken into consideration while studying the topic in this context. 
Executives and managers of airlines may also find these results interesting and informative in regard to their sustainability strategy. Specifically, our findings could help the managers to allocate available resources to ESG activities by adopting more efficient and robust approaches. The current study also highlights the potential moderation role of size in building a sustainability scheme. We provide evidence for managers of full-service airlines to consider prioritizing societal over environmental and governance activities when deciding to contribute to sustainability initiatives. So, our study findings provide policy implication for airline executives potentially allowing them to better allocate and utilize their firm's resources. Since this study has focused on a small proportion of airlines over a short period of time, future research might cover a larger sample of airlines over a longer period. Thus, broadening the scope of the analysis would provide a more comprehensive view on the topic. Additionally, it is suggested that future studies on the current topic may test for the potential moderating effect of leverage, return on assets or dividends.

\section{Appendix 1}

See Table 8

Table 8 Thomson Reuters Eikon's ESG categories

\begin{tabular}{lll}
\hline Environmental & Social & Governance \\
\hline Resource use & Workforce & Management \\
Emissions & Human rights & Shareholders \\
Innovation & Community & CSR strategy \\
& Product responsibility & \\
\hline
\end{tabular}




\section{Appendix 2}

See Table 9

Table 9 Sampled airlines

\begin{tabular}{|c|c|c|c|}
\hline Country & Company name & Stock code & Date of incorporation \\
\hline Germany & Lufthansa & 823,212 (LHA) & 06/01/1953 \\
\hline Hong Kong & Pacific airways & 293 & $17 / 10 / 1948$ \\
\hline France & KLM & FR0000031122 (AIRF) & $31 / 12 / 1954$ \\
\hline Singapore & Singapore airlines & C6L (SIAL) & 27/01/1972 \\
\hline Sweden & SAS AB & SE0003366871 (SAS) & $31 / 12 / 1945$ \\
\hline United Kingdom & Easy jet & B7KR2P8 (EZJ) & $23 / 03 / 2000$ \\
\hline Republic of Ireland & Ryanair & IE00BYTBXV33 (RYA) & 04/06/1996 \\
\hline Japan & ANA holding group & 9202 & $26 / 12 / 1952$ \\
\hline United States of America & Alaska Air group Inc & $000,011,659,109$ (ALK) & $14 / 03 / 1985$ \\
\hline Thailand & Thai airways & THAI & $28 / 03 / 1960$ \\
\hline Taiwan & China airlines & 2610 & 06/09/1959 \\
\hline South Korea & Korean air & 003,490 & $18 / 06 / 1962$ \\
\hline Taiwan & Eva airways & 2618 & 06/04/1989 \\
\hline China & China Southern airlines & 600,029 & 24/03/1995 \\
\hline Brazil & Gol transportes aéreos & GOLL4 & $11 / 03 / 2004$ \\
\hline China & Air China & 601,111 & $26 / 03 / 2006$ \\
\hline Canada & Air Canada & 000,008,911,877 (AC) & $23 / 11 / 2006$ \\
\hline United States of America & JetBlue & 000,477,143,101 (JBLU) & 23/08/1998 \\
\hline United States of America & Delta air & $000,247,361,702(\mathrm{DAL})$ & $15 / 03 / 1967$ \\
\hline Chile & LATAM airlines & LTM & 07/08/1986 \\
\hline Panama & Copa holdings SA & $000,000,000,000$ (CPA) & 05/05/1998 \\
\hline United States of America & United airlines & 000,910,047,109 (UAL) & $29 / 12 / 1968$ \\
\hline Japan & Japan airlines & 9201 & $31 / 07 / 1951$ \\
\hline Turkey & Turk Hava Yollari & THYAO & $29 / 01 / 1960$ \\
\hline Malaysia & Airasia group & 5099 (AIRA) & $23 / 08 / 2017$ \\
\hline United Kingdom & $\begin{array}{l}\text { Consolidated airlines group } \\
\text { SA }\end{array}$ & B5M6XQ7 (ICAG) & $23 / 12 / 2009$ \\
\hline Australia & Qantas airlines & QAN & $17 / 01 / 1934$ \\
\hline Canada & ACE aviation & 00000440P409 (ACEh) & $13 / 12 / 2007$ \\
\hline China & China Eastern airlines & 600,115 & $13 / 04 / 1995$ \\
\hline United States of America & SkyWest Inc & 000,830,879,102 (SKYW) & 01/03/1972 \\
\hline United States of America & Hawaiian airlines & $000,419,879,101(\mathrm{HA})$ & $23 / 04 / 2002$ \\
\hline New Zealand & Air New Zealand & AIR & $25 / 04 / 1940$ \\
\hline United States of America & Spirit airlines & $000,848,577,102$ (SAVE) & 07/03/1994 \\
\hline Panama & Avianca holding & PAI69PA00017(AVT_p) & $02 / 03 / 2011$ \\
\hline India & Interglobe aviation & EQINDIGO (INGL) & $12 / 01 / 2004$ \\
\hline Australia & Virgin Australia & $\mathrm{VAH}$ & $29 / 12 / 2000$ \\
\hline Switzerland & Wizz air & BN574F9 (WIZZ) & $02 / 06 / 2009$ \\
\hline China & Spring airlines & 601,021 & $31 / 10 / 2004$ \\
\hline
\end{tabular}

The codes in parenthesis are refinitiv identification code (RIC) of airlines in Eikon database framework 


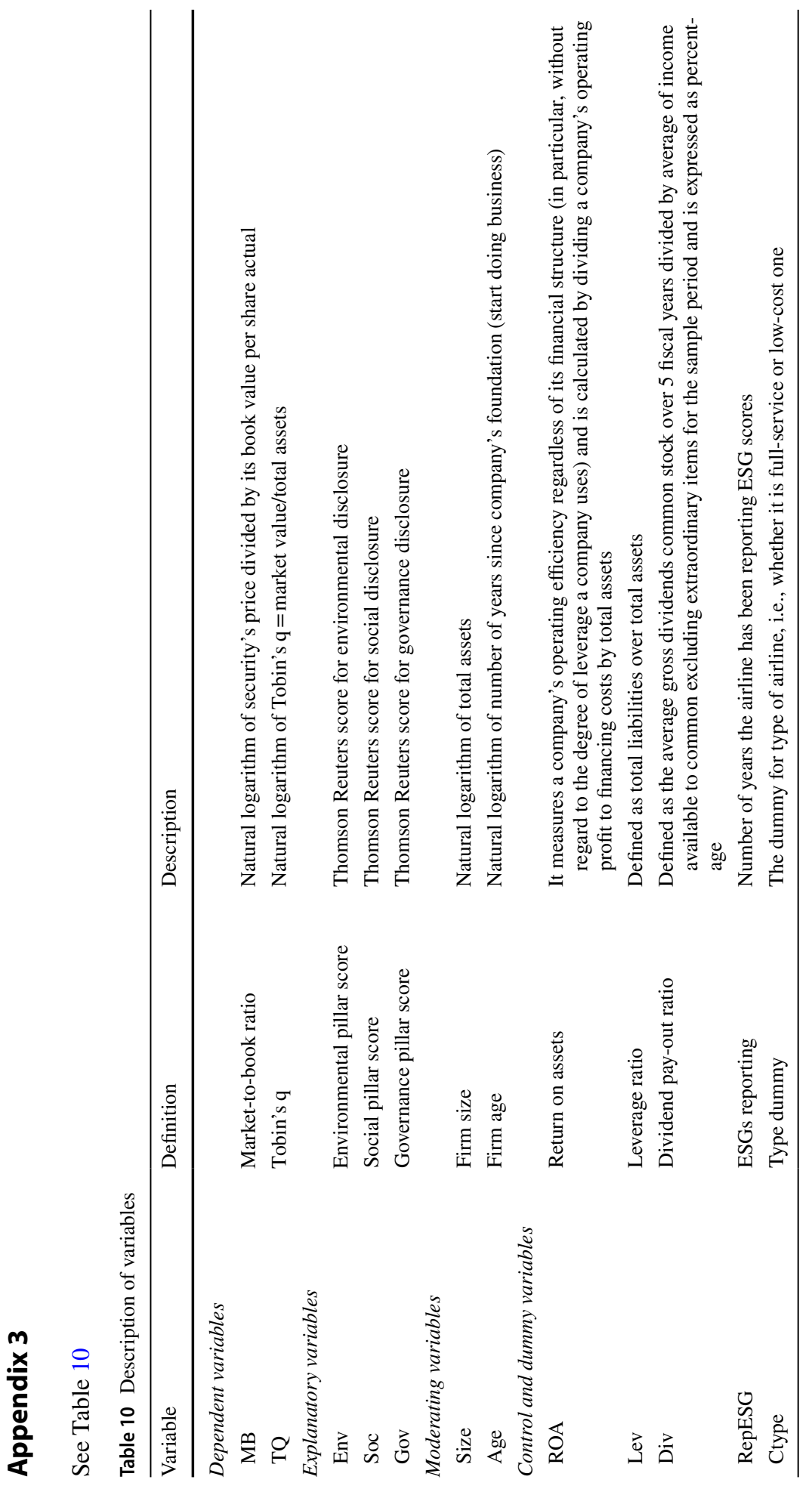




\section{Appendix 4}

This study followed the econometric strategy according to Princeton panel data analysis (Torres-reyna, 2010), to verify the relevant fit predictor in the environment of R-studio software (RStudio Team 2020), using utilities in the R-package 'plm'(Croissant and Millo 2008).

Supplementary Information The online version contains supplementary material available at https:/doi. org/10.1007/s10668-021-01649-w.

Authors' contributions All authors listed have significantly contributed to the development and the writing of this article.

Funding Open Access funding provided thanks to the CRUE-CSIC agreement with Springer Nature. This project has received funding from European Union's Horizon 2020 research and innovation program under the Marie Skłodowska-Curie grant agreement NO. 713679 and from the Universitat Rovira i Virgili (URV).

\section{Declaration}

Conflict of interest The authors declare that there is no conflict of interest.

Open Access This article is licensed under a Creative Commons Attribution 4.0 International License, which permits use, sharing, adaptation, distribution and reproduction in any medium or format, as long as you give appropriate credit to the original author(s) and the source, provide a link to the Creative Commons licence, and indicate if changes were made. The images or other third party material in this article are included in the article's Creative Commons licence, unless indicated otherwise in a credit line to the material. If material is not included in the article's Creative Commons licence and your intended use is not permitted by statutory regulation or exceeds the permitted use, you will need to obtain permission directly from the copyright holder. To view a copy of this licence, visit http://creativecommons.org/licenses/by/4.0/.

\section{References}

Aouadi, A., \& Marsat, S. (2018). Do ESG controversies matter for firm value? Evidence from international data. Journal of Business Ethics, 151(4), 1027-1047.

Barnea, A., \& Rubin, A. (2010). Corporate social responsibility as a conflict between shareholders amir barnea. Journal of Business Ethics, 97(1), 71-86.

Baron, D. P. (2000). Business and its environment (3rd ed.). Prentice Hall.

Barrutia, J. M., \& Echebarria, C. (2015). Resource-based view of sustainability engagement. Global Environmental Change, 34, 70-82.

Belobaba, P., Odoni, A., \& Barnhart, C. (2009). The global airline industry. John Wiley \& Sons.

Birindelli, G., Dell'Atti, S., Iannuzzi, A. P., et al. (2018). Composition and activity of the board of directors : Impact on esg performance in the banking system. Sustainability, 12(10), 4699.

Borghesi, R., Houston, J. F., \& Naranjo, A. (2014). Corporate socially responsible investments : CEO altruism, reputation, and shareholder interests. Journal of Corporate Finance, 26, 164-181.

Brammer, S., \& Millington, A. (2005). Corporate reputation and philanthropy : An empirical analysis. Journal of Business Ethics, 61, 29-44.

Branco, M. C., \& Rodrigues, L. L. (2006). Corporate social responsibility and resource-based perspectives. Journal of Business Ethics, 69(2), 111-132.

Brogi, M., \& Lagasio, V. (2019). Environmental, social, and governance and company profitability: Are financial intermediaries different? Corporate Social Responsibility and Environmental Management, 26(3), $576-587$.

Bryson, J. M., Ackermann, F., \& Eden, C. (2007). Putting the resource-based view of strategy and distinctive competencies to work in public organizations. Public Administration Review, 67(4), 702-717. 
Buallay, A. (2019). Between cost and value: Investigating the effects of sustainability reporting on a firm's performance. Journal of Applied Accounting Research, 20(4), 481-496.

Campbell, J. L. (2007). Why would corporations behave in socially responsible ways? An institutional theory of corporate social responsibility. Academy of Management Review, 32(3), 946-967.

Casado-Díaz, A., Nicolau, J., Ruiz-Moreno, F., et al. (2014). Industry-specific effect of CSR initiatives: Hotels and airlines. Kybernetes, 43(3), 547-564.

Croissant, Y., \& Millo, G. (2008). Panel Data Econometrics in R: The plm Package. Journal of Statistical Software, 27(2).

D’Amato, A., \& Falivena, C. (2020). Corporate social responsibility and firm value: Do firm size and age matter? Empirical evidence from European listed companies. Corporate Social Responsibility and Environmental Management, 27(2), 909-924.

Daley, B. (2010). Air transport and the environment. Ashgate.

Dessens, O., Köhler, M. O., Rogers, H. L., Jones, R. L., et al. (2014). Aviation and climate change. Transport Policy, 34, 1-7.

Dhaliwal, D. S., Li, O. Z., Tsang, A., et al. (2011). Voluntary nonfinancial disclosure and the cost of equity capital: The initiation of corporate social responsibility reporting. The Accounting Review, 86(1), 59-100.

Dhaliwal, D. S., Radhakrishnan, S., Tsang, A., et al. (2012). Nonfinancial disclosure and analyst forecast accuracy: International evidence on corporate social responsibility disclosure. The Accounting Review, 87(3), 723-759.

Diez-Cañamero, B., Bishara, T., Otegi-Olaso, J. R., et al. (2020). Measurement of corporate social responsibility: A review of corporate sustainability indexes, rankings and ratings. Sustainability, 12(5), 2153.

Drempetic, S., Klein, C., \& Zwergel, B. (2019). The influence of firm size on the esg score: Corporate sustainability ratings under review. Journal of Business Ethics, 167(2), 1-28.

Driver, C., \& Thompson, G. (2002). Corporate governance and democracy: The stakeholder debate revisited. Journal of Management and Governance, 6, 111-130.

Duque-Grisales, E., \& Aguilera-Caracuel, J. (2019). Environmental, social and governance (esg) scores and financial performance of multilatinas: Moderating effects of geographic international diversification and financial slack. Journal of Business Ethics, 168(2), 1-20.

Eikon. (2017). Thomson reuters ESG scores. Retrieved from https://www.esade.edu/itemsweb/biblioteca/bbdd/ inbbdd/archivos/Thomson_Reuters_ESG_Scores.pdf.

Fama, E. F., \& French, K. R. (1995). Size and book-to-market factors in earnings and returns. The Journal of Finance, 50(1), 131-155.

Fatemi, A., Glaum, M., \& Kaiser, S. (2018). ESG performance and firm value: The moderating role of disclosure. Global Finance Journal, 38, 45-64.

Ferrero-Ferrero, I., Fernández-Izquierdo, M. Á., \& Muñoz-Torres, M. J. (2016). The effect of environmental, social and governance consistency on economic results. Sustainability, 8(10), 1005.

Forsyth, P. (2011). Environmental and financial sustainability of air transport: Are they incompatible? Journal of Air Transport Management, 17(1), 27-32.

Friede, G., Busch, T., \& Bassen, A. (2015). ESG and financial performance: Aggregated evidence from more than 2000 empirical studies. Journal of Sustainable Finance and Investment, 5(4), 210-233.

Gillan, S. L., Hartzell, J. C., Koch, A., \& Starks, L. (2010). Firms' environmental, social and governance (ESG) choices, performance and managerial motivation. Unpublished working paper. Texas Tech University and University of Texas at Austin. http://www.pitt.edu/ awkoch/ESG\%20Nov\%202010.pdf.

Gillan, S. L., Koch, A., \& Starks, L. T. (2021). Firms and social responsibility: A review of ESG and CSR research in corporate finance. Journal of Corporate Finance, 66, 101889.

Godfrey, P. C. (2013). Philanthropy and shareholder wealth : The relationship between corporate a risk management perspective. The Academy of Management Review, 30(4), 777-798.

Gordon, M. J. (1959). Dividends, earnings, and stock prices. The Review of Economics and Statistics, 41(2), 99-105.

Grosbois, D. (2012). Corporate social responsibility reporting by the global hotel industry: Commitment, initiatives and performance. International Journal of Hospitality Management, 31(3), 896-905.

Gupta, M. C. (1969). The effect of size, growth, and industry on the financial structure of manufacturing companies. Journal of Finance, 24(3), 517-529.

Hagmann, C., Semeijn, J., \& Vellenga, D. B. (2015). Exploring the green image of airlines: Passenger perceptions and airline choice. Journal of Air Transport Management, 43, 37-45.

Hill, J. (2020). Environmental, social, and governance (ESG) investing: A balanced analysis of the theory and practice of a sustainable portfolio. Academic Press.

Howard-Grenville, J. (2021). ESG impact is hard to measure-but it's not impossible. Harvard business review. https://hbr.org/2021/01/esg-impact-is-hard-to-measure-but-its-not-impossible. 
Jensen, A. L. (2020). Stock Market Reactions to Environmental, Social and Governance-related Events: An event study of H\&M group [Master's Thesis, Copenhagen Business School]. https://research.cbs.dk/en/ studentProjects/stock-market-reactions-to-environmental-social-and-governance-rel

Jo, H., \& Harjoto, M. A. (2011). Corporate governance and firm value: The impact of corporate social responsibility. Journal of Business Ethics, 103(3), 351-383.

Kim, B., \& Lee, S. (2020). The impact of material and immaterial sustainability on firm performance: The moderating role of franchising strategy. Tourism Management, 77, 103999.

Lahouel, B. B., Gaies, B., Zaied, Y. B., \& Jahmane, A. (2019). Accounting for endogeneity and the dynamics of corporate social-Corporate financial performance relationship. Journal of Cleaner Production, 230, 352-364.

Lee, S., \& Park, S. Y. (2010). Financial impacts of socially responsible activities on airline companies. Journal of Hospitality and Tourism Research, 34(2), 185-203.

Lee, D. D., Faff, R. W., \& Langfield-Smith, K. (2009). Revisiting the vexing question: Does superior corporate social performance lead to improved financial performance? Australian Journal of Management, 34(1), 21-49.

Lee, S., Seo, K., \& Sharma, A. (2013). Corporate social responsibility and firm performance in the airline industry: The moderating role of oil prices. Tourism Management, 38, 20-30.

Li, Y., Gong, M., Zhang, X. Y., \& Koh, L. (2018). The impact of environmental, social, and governance disclosure on firm value: The role of CEO power. British Accounting Review, 50(1), 60-75.

Long, W., Li, S., Wu, H., \& Song, X. (2020). Corporate social responsibility and financial performance: The roles of government intervention and market competition. Corporate Social Responsibility and Environmental Management, 27(2), 525-541.

López-Pérez, M. E., Melero, I., \& Javier-Sese, F. (2017). Management for sustainable development and its impact on firm value in the SME context: Does size matter? Business Strategy and the Environment, 26(7), 985-999.

Malighetti, P., Meoli, M., Paleari, S., et al. (2011). Value determinants in the aviation industry. Transportation Research Part E Logistics and Transportation Review, 47(3), 359-370.

Malik, M. (2014). Value-enhancing capabilities of CSR: A brief review of contemporary literature. Journal of Business Ethics, 127(2), 419-438.

Margolis, J. D., \& Walsh, J. P. (2001). People and profits?: The search for a link between a company's social and financial performance. Lawrence Erlbaum Associates.

McManners, P. (2016a). The action research case study approach: A methodology for complex challenges such as sustainability in aviation. Action Research, 14(2), 201-216.

McManners, P. J. (2016b). Developing policy integrating sustainability: A case study into aviation. Environmental Science and Policy, 57, 86-92.

McWilliams, A., \& Siegel, D. (2001). Corporate social responsibility: A theory of the firm perspective. Academy of Management Review, 26(1), 117-127.

McWilliams, A., Siegel, D., \& Teoh, S. H. (1999). Issues in the use of the event study methodology: A critical analysis of corporate social responsibility studies. Organizational Research Methods, 2(4), 340-365.

Miralles-Quirós, M. M., Miralles-Quirós, J. L., \& Redondo-Hernández, J. (2019). The impact of environmental, social, and governance performance on stock prices: Evidence from the banking industry. Corporate Social Responsibility and Environmental Management, 26(6), 1446-1456.

Moneva, J. M., Bonilla-priego, M. J., \& Ortas, E. (2020). Corporate social responsibility and organisational performance in the tourism sector. Journal of Sustainable Tourism, 28(6), 853-872.

Moon, J., Lee, W. S., \& Dattilo, J. (2015). Determinants of the payout decision in the airline industry. Journal of Air Transport Management, 42, 282-288.

Moore, G. (2001). Corporate social and financial performance: An investigation in the UK supermarket industry. Journal of Business Ethics, 34(3), 299-315.

Nidumolu, R., Prahalad, C. K., \& Rangaswami, M. R. (2009). Why sustainability is now the key driver of innovation. Harvard Business Review, 87(9), 56-64.

Okafor, A., Adusei, M., \& Adeleye, B. N. (2021). Corporate social responsibility and financial performance: Evidence from U S tech firms. Journal of Cleaner Production, 292, 126078.

Park, S. Y., \& Lee, S. (2009). Financial rewards for social responsibility: A mixed picture for restaurant companies. Cornell Hospitality Quarterly, 50(2), 168-179.

Park, S., Song, S., \& Lee, S. (2017). Corporate social responsibility and systematic risk of restaurant firms: The moderating role of geographical diversification. Tourism Management, 59, 610-620.

Pavlopoulos, A., Magnis, C., \& Iatridis, G. E. (2019). Integrated reporting: An accounting disclosure tool for high quality financial reporting. Research in International Business and Finance, 49, 13-40.

Peloza, J. (2006). Using corporate social responsibility as insurance for financial performance. California Management Review, 48(2), 52-72. 
Pires, H. M., \& Fernandes, E. (2012). Malmquist financial efficiency analysis for airlines. Transportation Research Part E Logistics and Transportation Review, 48(5), 1049-1055.

Pruitt, S. W., \& Chung, K. H. (1994). A simple approximation of Tobin's q. Financial Management, 23(3), 3-15.

Qiu, Y., Shaukat, A., \& Tharyan, R. (2016). Environmental and social disclosures: Link with corporate financial performance. The British Accounting Review, 48(1), 102-116.

Qureshi, M. A., Kirkerud, S., Theresa, K., et al. (2020). The impact of sustainability (environmental, social, and governance) disclosure and board diversity on firm value: The moderating role of industry sensitivity. Business Strategy and the Environment, 29(3), 1199-1214.

Roberts, R. W. (1992). Determinants of corporate social responsibility disclosure: An application of stakeholder theory. Accounting Organizations and Society, 17(6), 595-612.

Rowley, T., \& Berman, S. (2000). A brand new brand of corporate social performance. Business and Society, 39(4), 397-418.

RStudio Team. (2020). R-Studio: Integrated Development for R. R-Studio,. PBC, Boston, MA. http://www. rstudio.com/

Saeidi, S. P., Sofian, S., Saeidi, P., et al. (2015). How does corporate social responsibility contribute to firm financial performance? The mediating role of competitive advantage, reputation, and customer satisfaction. Journal of Business Research, 68(2), 341-350.

Seo, K., Moon, J., \& Lee, S. (2015). Synergy of corporate social responsibility and service quality for airlines: The moderating role of carrier type. Journal of Air Transport Management, 47, 126-134.

Serafeim, G. (2020). Public sentiment and the price of corporate sustainability. Financial Analysts Journal, $76(2), 26-46$.

Song, H. J., Yeon, J., \& Lee, S. (2021). Impact of the COVID-19 pandemic: Evidence from the US restaurant industry. International Journal of Hospitality Management, 92, 102702.

Taherdangkoo, M., Ghasemi, K., \& Beikpour, M. (2017). The role of sustainability environment in export marketing strategy and performance: A literature review. Environment Development and Sustainability, 19(5), 1601-1629.

Taylor, M., \& Oinas, P. (2006). Understanding the firm: Spatial and organizational dimensions. Oxford University Press Inc.

Theodoulidis, B., Diaz, D., Crotto, F., \& Rancati, E. (2017). Exploring corporate social responsibility and financial performance through stakeholder theory in the tourism industries. Tourism Management, 62, 173-188.

Torres-reyna, O. (2010). Panel data using R-slides princeton university. Princeton University, 28. https:// www.princeton.edu/ otorres/Panel101R.pdf.

Udayasankar, K. (2008). Corporate social responsibility and firm size. Journal of Business Ethics, 8(32), $167-175$.

Videras, J. R., \& Owen, A. L. (2006). Public goods provision and well-being: Empirical evidence consistent with the warm glow theory. The BE Journal of Economic Analysis and Policy. https://doi.org/10.1515/ 1538-0645.1531

Waddock, S. A., \& Graves, S. B. (1997). The corporate social performance-financial performance link. Stategic Manajemen Journal, 18(4), 303-319.

Withisuphakorn, P., \& Jiraporn, P. (2015). The effect of firm maturity on corporate social responsibility (CSR): Do older firms invest more in CSR? Applied Economics Letters, 23(4), 298-301.

Xie, J., Nozawa, W., Yagi, M., et al. (2019). Do environmental, social, and governance activities improve corporate financial performance? Business Strategy and the Environment, 28(2), 286-300.

Yaffee, R. (2003). A primer for panel data analysis. Connect Information Technology at NYU, Fall Edition, pp 1-11. http://web.pdx.edu/ crk1/ec510/pda_yaffee.pdf

Yang, A. S., \& Baasandorj, S. (2017). Exploring CSR and financial performance of full-service and lowcost air carriers. Finance Research Letters, 23, 291-299.

Publisher's Note Springer Nature remains neutral with regard to jurisdictional claims in published maps and institutional affiliations. 